\title{
On the Positive Electrification of Snow Crystals in the Process of Their Melting (III)
}

\author{
- The relationship between air bubble concentration and charge \\ generated in ice specimen during their melting-
}

\section{By Katsuhiro Kikuchi}

Department of Geophysics, Hokkaido University, Sapporo

(Manuscript received 25 August 1965, in revised form 15 November 1965)

\begin{abstract}
From the experimental and observational results to date (Magono and Kikuchi, 1963, 1965), it has been known that snow crystals and ice specimens acquire some positive charge during their melting process. As it is thought that air bubbles which contained in snow crystals and ice specimens have some role to the mechanism of charge generation in their melting process, especially in this paper, the relationship between air bubble concentration in ice specimen and positive charge generation in the specimen during the process was confirmed experimentally. As a result, it was found that the positive charge acquired in the melting process was approximately proportional to the air bubble concentration contained in the ice specimen, and it was noted that the charge depended not only on the total volume of air bubbles in the specimen but also on the size of each bubble. In this experiment, the diameters which contribute to the mechanism of this charge generation ranged from several $\mu$ to $150 \mu$ with the mean volume diameter of $52 \mu$. And big air bubbles which the equivalent volume diameter is larger than $1 \mathrm{~mm}$ did not contribute to the mechanism. Accordingly, it was noted that a great number of small air bubbles are im. portant in the charge generation in the melting process.
\end{abstract}

\section{Introduction}

In the previous paper (Magono and Kikuchi, 1965), it was reported that natural snow crystals were charged positively in their melting process during their falling. Furthermore, it was ascertained that natural snow crystals of various shapes and ice specimens suspended by a fine string were charged positively when they were melted in the horizontal D.C. electric field. From these experimental and observational results, it was also recognized that the more complicated and larger the snow crystals, the greater the magnitude of positive charge after melting they obtained. Furthermore, it was observed that numerous small air bubbles appeared from the surface of the melting snow crystals and burst in rapid succession, and that numerous tiny particles scattered from them in the melting process. Dinger and
Gunn (1946), Bent and Hutchinson (1965) found that melting ice specimens and melting snow on the ground acquired some positive charge. Dinger and Gunn measured the space charge separated from melting ice specimens on a platinum pan, and Bent and Hutchinson observed electric space charge over melting snow on the ground. In either case the measurement of the charge of melting ice or snow itself was not done. Dinger and Gunn assumed that some kinds of the dissolved gases entrapped in ice in the form of small bubbles when released played an important role for the positive electrification of melting ice specimens. But, no quantitative determination of the relationship between gas bubble concentration and the amount of charge was made.

In this paper, the quantitative determination of the relationship between air bubble 
concentration in the ice specimens and amount of charges separated was made. In the present experiment, the charge of ice specimen was directly measured.

\section{Experimental procedures}

The ice specimens for the experiment were prepared in the following manner. Three litres of distilled water was additionally purified by ion-exchange resin preparatory to making ice specimens. This was frozen in a cold room at approximately $-15^{\circ} \mathrm{C}$ for 2 to 5 days in a plastic container (dia. $15 \mathrm{~cm}$, depth $20 \mathrm{~cm}$ ). In most cases the ice specimens were polycrystals. For the experiment, an ice specimen was cut from the above prepared ice lump, and weighed. To check the presence or absence of air bubbles, cracks and grain boundaries in the specimens, observations were made by crossed artificial polarizers and photographed using a close-up lens camera. Then, the specimen was placed on a brass cylindrical container (dia. $7 \mathrm{~cm}$, depth $1 \mathrm{~cm}$ ) which was connected to a vacuum-tube electrometer (Magono and Orikasa, 1960). The specimen was melted with a warm air current, according to Matthews and Mason's method (1963). This experiment was carried out in a cold room at $-15^{\circ} \mathrm{C}$. The melting rate in this experiment was approximately $1 \mathrm{gram} \cdot \mathrm{min}^{-1}$. The experimental apparatus is shown at the left part of Photo. 1.

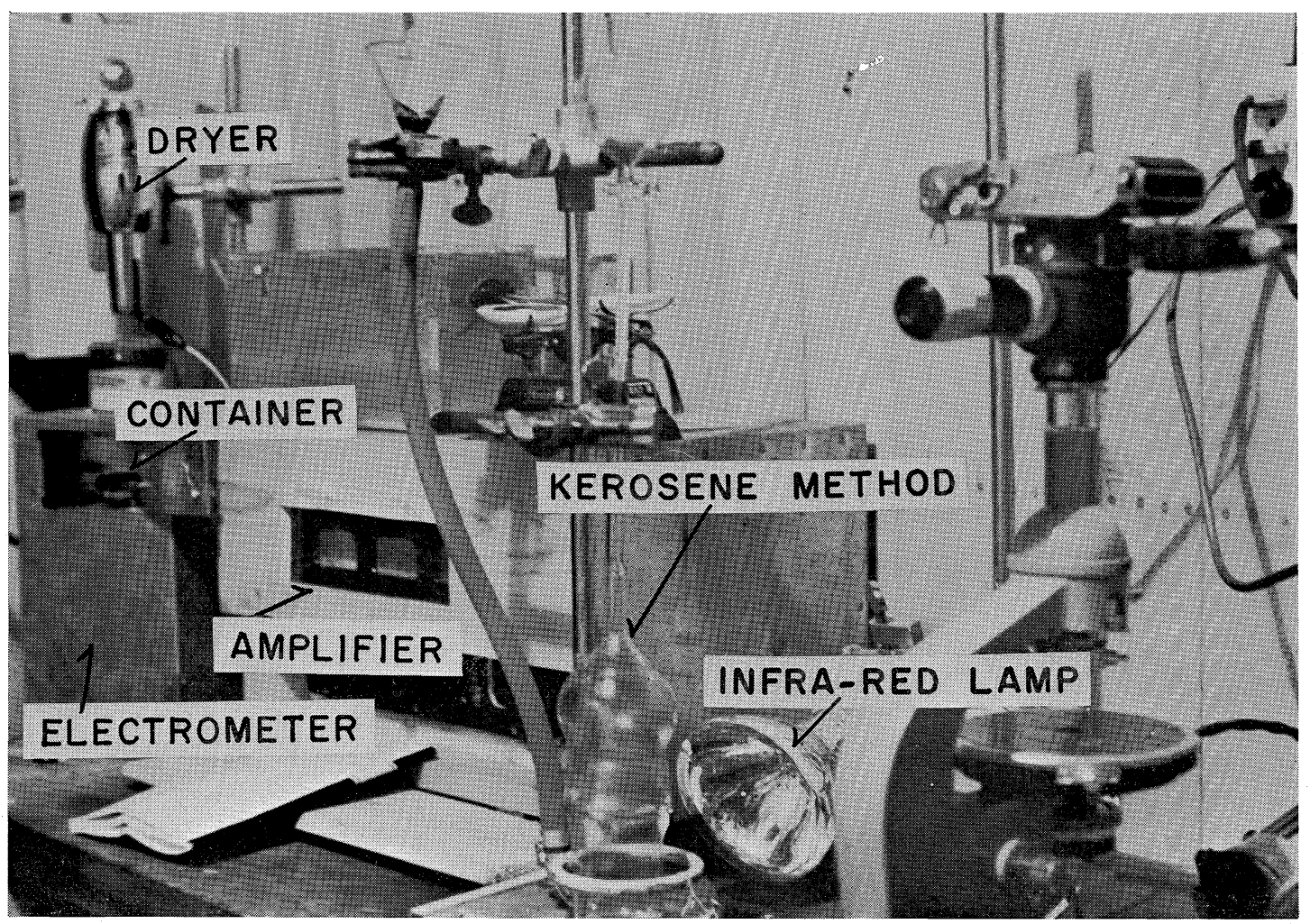

Photo 1. Experimental apparatus.

3. Melting experiments of ice specimens of various air bubble concentrations

\section{1) Ice specimens}

This experiment was carried out to measure how air bubble concentration in the ice specimens contributed to the charge generation.
Ice specimens were cut from the lump of ice prepared as described above. These were divided into the following four groups according to air bubble concentration; i.e. many bubbles, a few bubbles, no bubbles and cracks only. The masses of specimens for measurements ranged from 2 to 15 grams. Further- 
more, pure single ice crystals (Higashi, et al.) were used for measurement in order to compare the effect of grain boundary and impurities, if any.

\section{2) Results}

The experimental results are summarized in Fig. 1. In this figure, the ordinate and abscissa show the mass of ice specimens and the amount of charge respectively, and the narrow area between the two broken lines correspond to the marginal error of the experiment. As seen in this figure, all specimens with many air bubbles were charged positively by melting. On the other hand, almost all specimens of other groups were

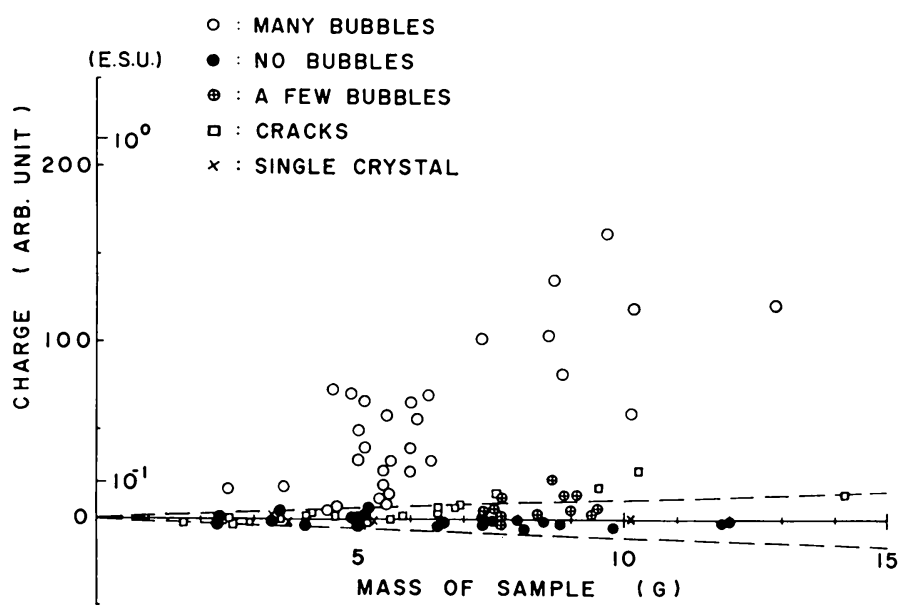

Fig. 1. Charges on various ice specimens.

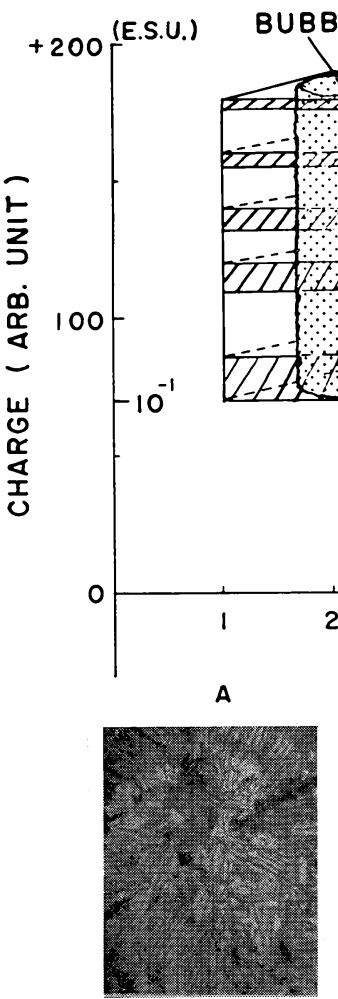

Fig. 2. Charges on ice specimens contained many air bubbles
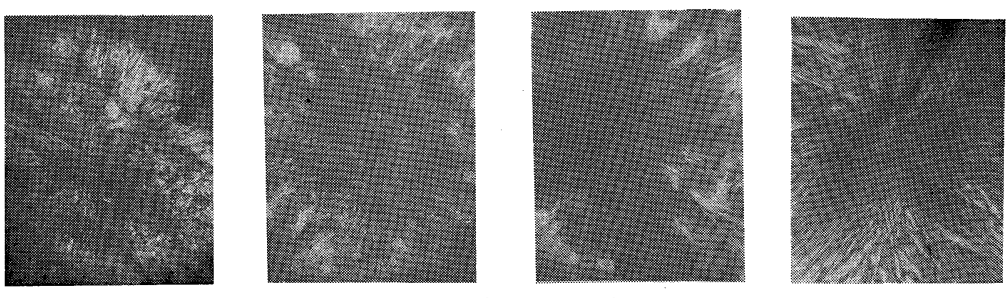

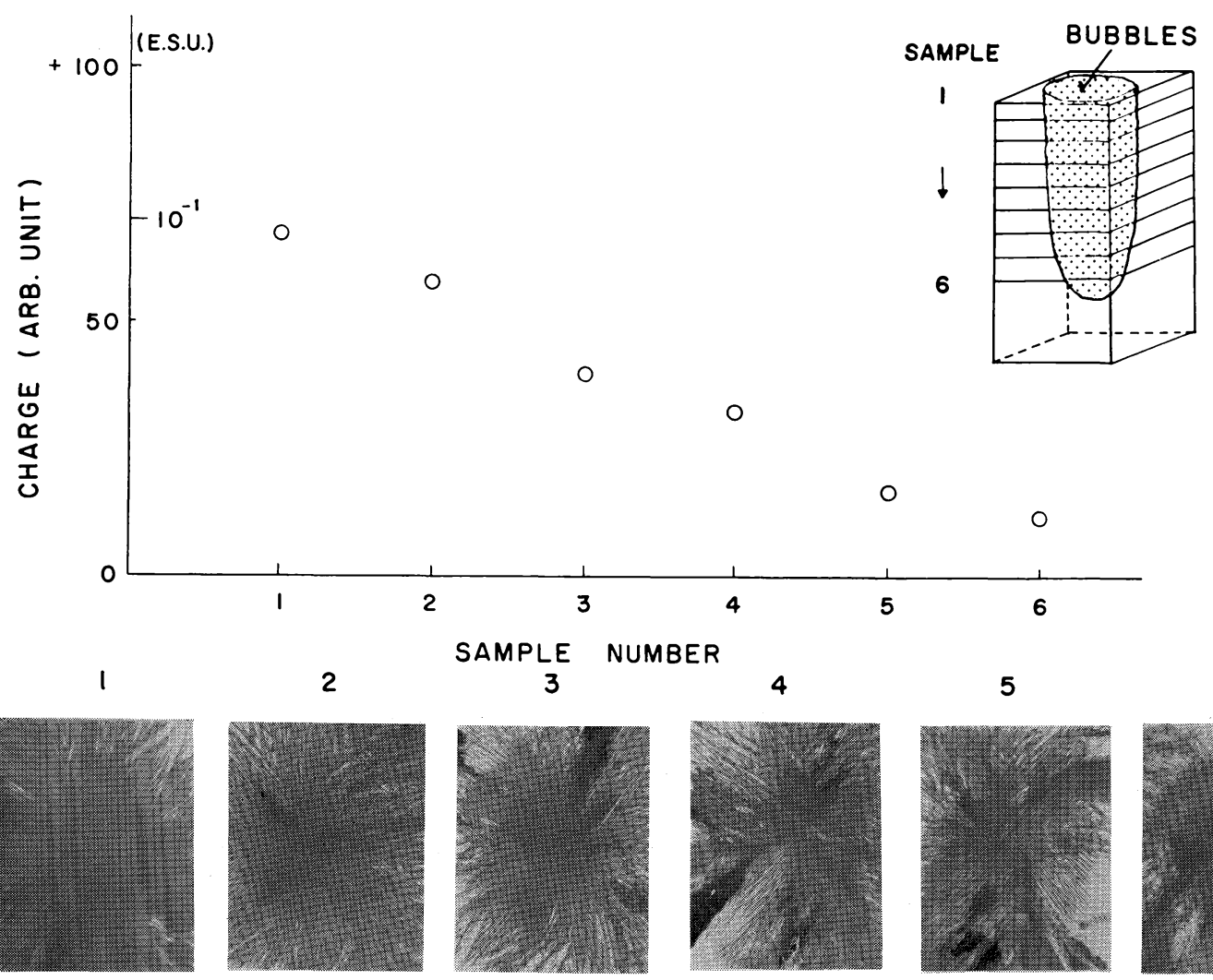

○

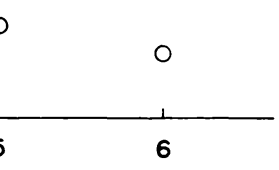

SAMPLE NUMBER

2

3

4

5

6
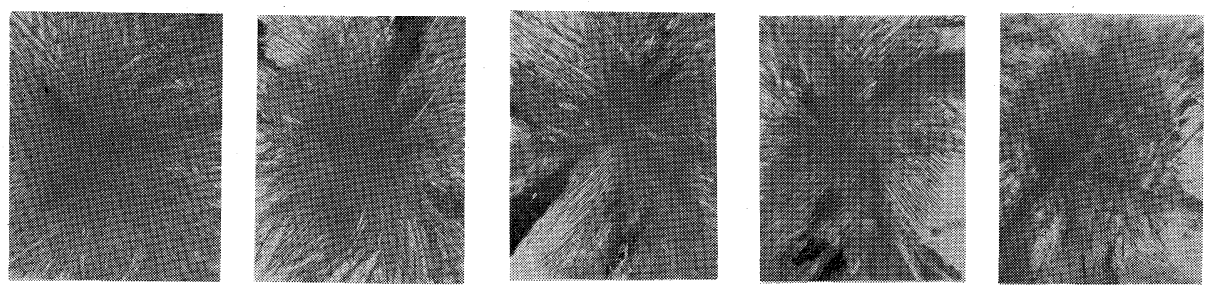

Fig. 3. Charges on ice specimens contained many air bubbles.

not appreciably charged in either sign. Also, from the figure, it may be recognized that the charges showed a tendency to be proportional to the mass of specimens. This tendency is more clear in the following Figs. 2 and 3 . In order to check the effect of air bubbles, ice specimens with a vertically uniform air bubble distribution, as seen in the upper left of Fig. 2, were chosen. Five thin plates of different thickness were cut from the prepared ice specimens. The cutting is shown schematically in the figure. The difference in thickness indicates the difference in the concentration of air bubbles. Fig. 2 shows the result of such two experiments, as expressed in black and white dots. Both

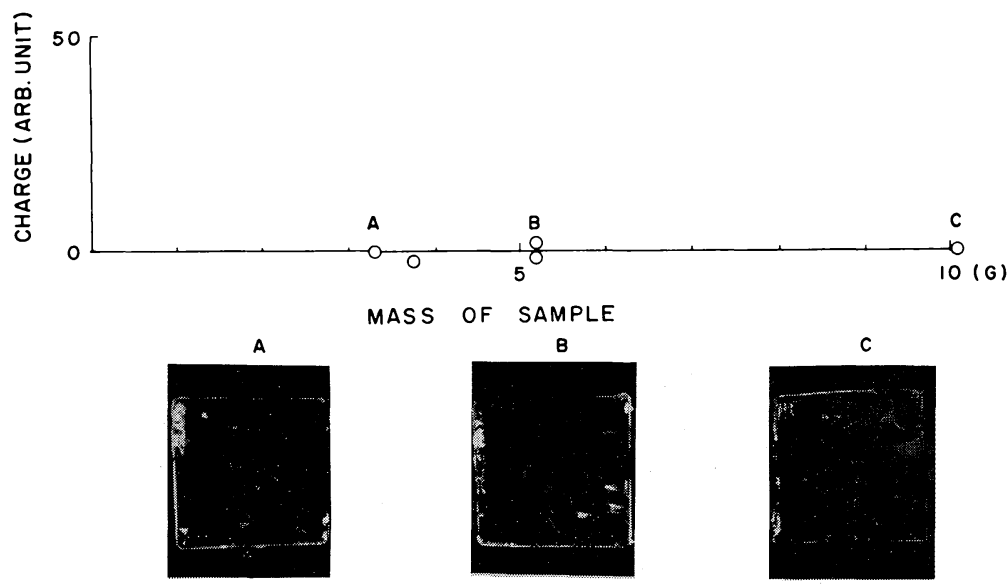

Fig. 4. Charges on single ice crystals. 
results show that the increase in mass of specimens corresponds to the increase in charges. Photographs under the abscissa show the section of ice specimens from specimen numbers $\mathrm{A}$ to $\mathrm{E}$ of different thickness. It may be seen that the thicker the specimen the greater the amount of air bubbles. Further, another experiment was made to check the effect of air bubbles. Fig. 3 shows a specimen of a uniform thickness in which air bubble concentration was distributed in a conical shape (shown on the right side upper). In this example, a decreasing concentration of air bubbles is seen with decreasing charges. Photographs of air bubble concentration corresponding to specimen numbers 1 to 6 are shown under the abscissa as in Fig. 3. In this case, likewise, a linear correlation between air bubble concentration and charges was recognized. Fig. 4 shows a case of specimens of single ice crystals in which the charge was not observed in spite of the mass, at least the charge was smaller than $10^{-3}$ esu. The single ice crystals contained no air bubbles as seen in photographs at the bottom of the figure.

\section{Relationship between air bubble concen- tration and charge}

\section{1) Measurement of air bubble concentration}

It was recognized in the experiment above that there was a close connection of charge generation in the melting process and air bubble concentration in ice specimens. In this section, air bubble concentration was measured quantitatively and the relationship of air bubbles to the separated charge was studied. The measurement of air bubble concentration in an ice specimen was carried out by Kerosene method (ІІулейкин. 1953, Kusunoki. 1958) in a cold room. The apparatus is as shown in the middle part of Photo. 1 and in Fig. 5 schematically. Infrared light was used as a heat source for melting. Two minutes after turning on the light, the ice specimen in the apparatus began to melt from the surface gradually, and numerous small air bubbles contained in the specimen were released from the surface of the specimen and accumulated in the upper part of the cylinder of the burette.

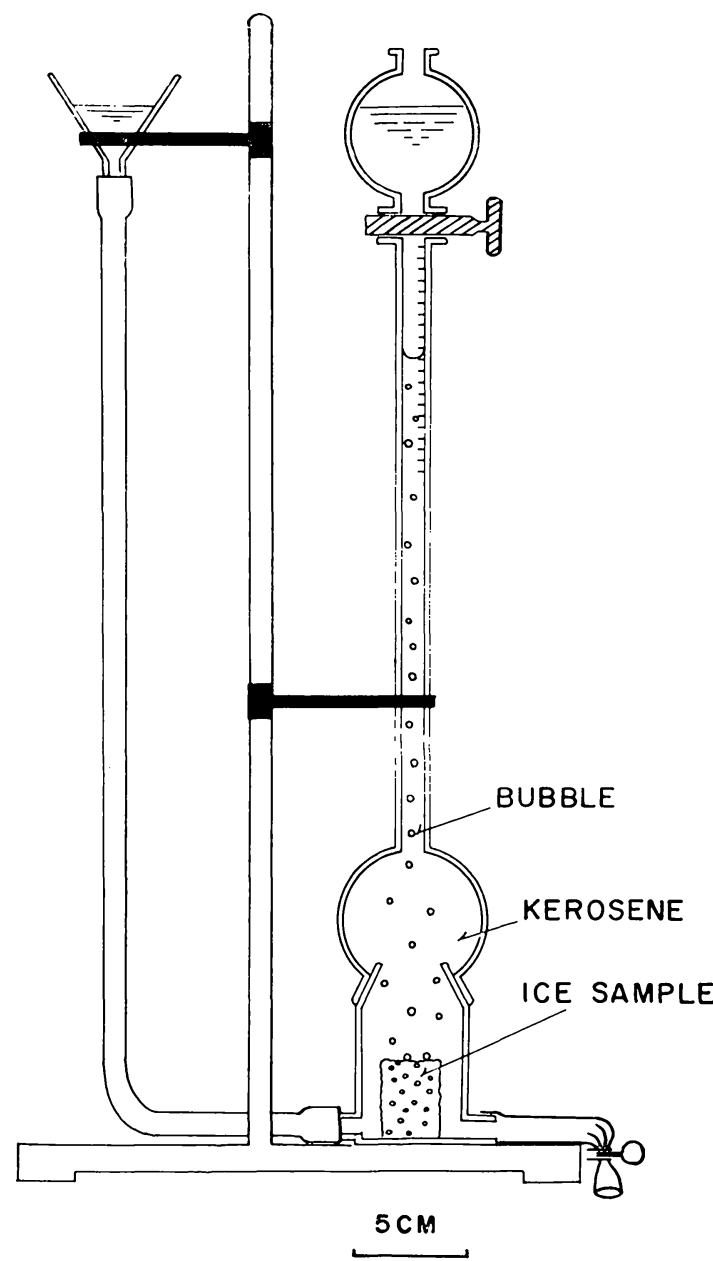

Fig. 5. Apparatus for measuring air bubbles in ice specimens (Kerosene method).

On the other hand, it was impossible to measure both the charge and the air bubble concentration from the same ice specimen, because by Kerosene method we were unable to measure the charge of ice during the measurement of air bubbles. Therefore, twin ice specimens of similar air bubble concentration and of the same mass were cut from as close to the same part of the lump of ice. Fig. 6 shows the grade of agreement between total volume of air bubbles of such twin ice specimens. In this figure, the coordinates show heights in $\mathrm{mm}$ which indicate the total volume of air bubbles in the burette. It may be seen that the plotted data are distributed along a straight line which passes the origin of the coordinates which has an inclination of $45^{\circ}$ to the abscissa. Therefore, it is con- 


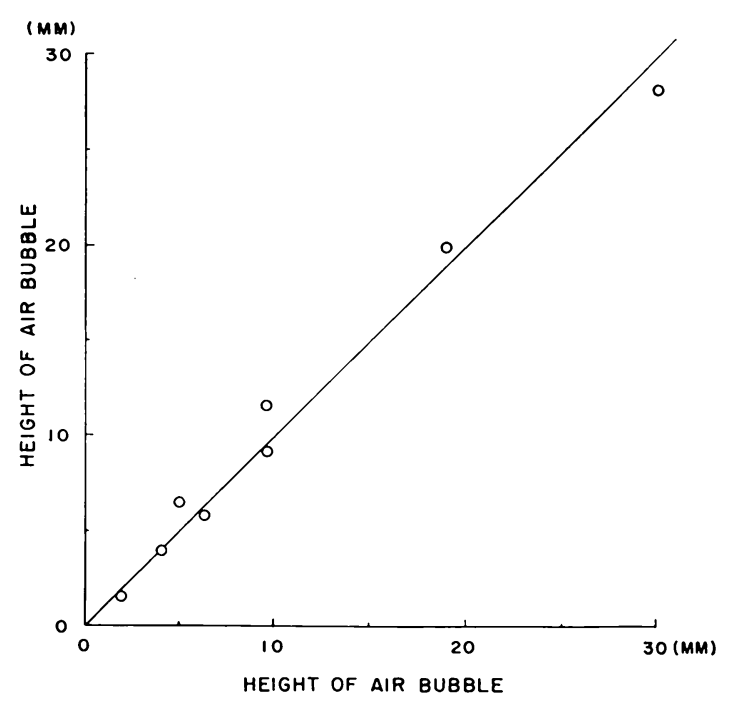

Fig. 6. Correlation between total volumes of air bubbles of two ice specimens.

sidered that the total volume of air bubbles of one ice specimen can represent that of the other ice.

\section{2) Results}

Air bubble concentrations were measured by the method as described above and three series of these experiments were carried out in order to find the relationship between the

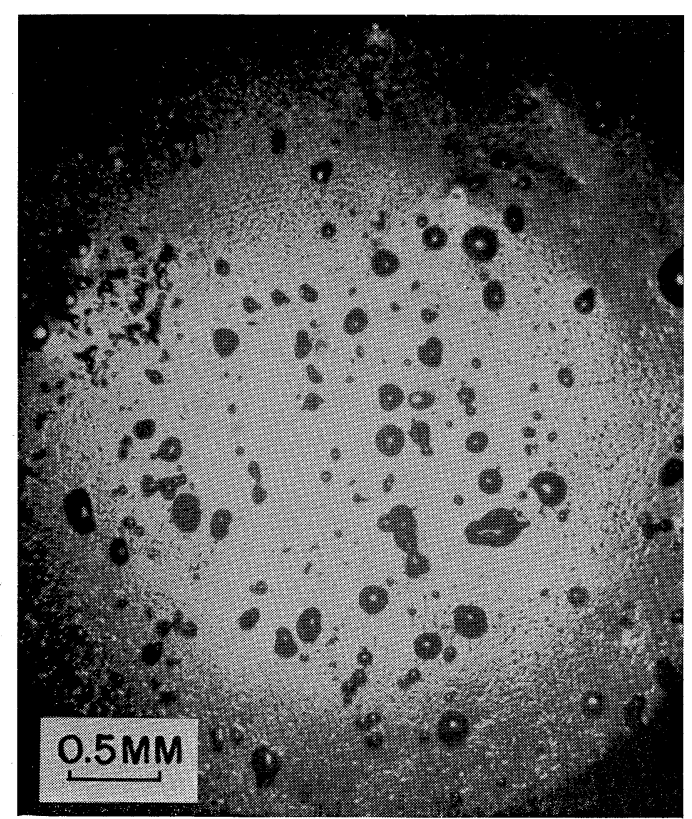

air bubbles and charges as shown in Fig. 7 . In the figure the ordinate shows the charge of melted ice in esu. gram $^{-1}$ and abscissa shows the air bubble concentration in ice in $\mathrm{cm}^{3} \cdot \mathrm{gram}^{-1}$ respectively. Although some scattering is seen around $5 \times 10^{-2} \mathrm{esu}^{\circ} \mathrm{gram}^{-1}$, the charge was approximately proportional to the air bubble concentration on the whole. In this experiment, the diameters of air bub-

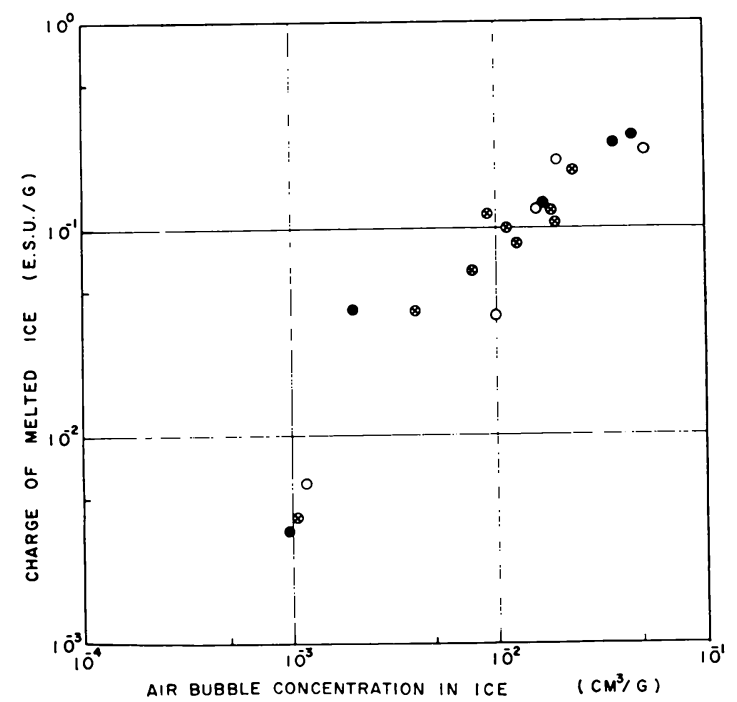

Fig. 7. Relationship between charges and air bubble concentration in ice.

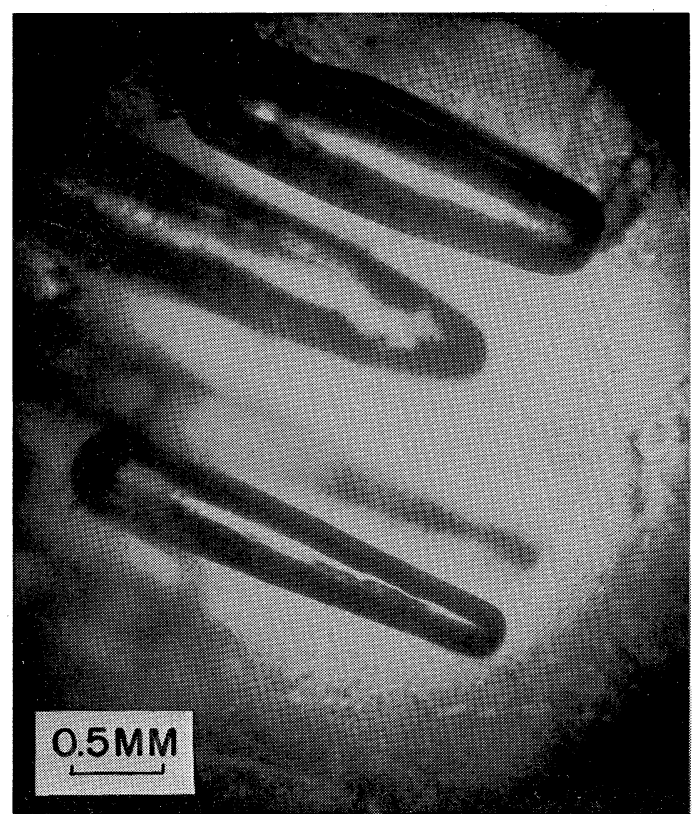

Photo 2. Microscopic photographs of small(a) and big air bubbles(b) contained in artificial ice specimens. 


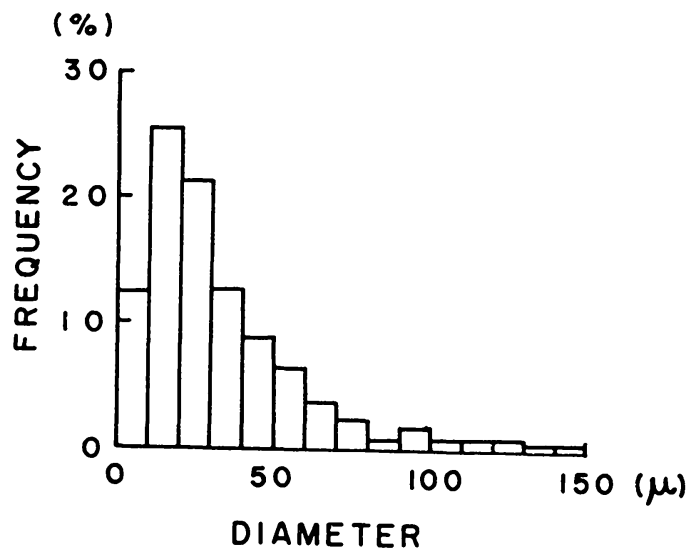

Fig. 8. Size distribution of air bubbles contained in an ice specimen.

bles ranged from several $\mu$ to $150 \mu$ with the mean volume diameter of $52 \mu$. A microscopic photograph of these air bubbles is shown in Photo. 2(a). Fig. 8 shows their size distribution. In these experiments, a few exceptions were observed, in which, in spite of high value of air bubble concentration, the ice specimen did not acquire the charge as expected from high air bubble concentration. Photo. $2(\mathrm{~b})$ shows a microscopic photograph of air bubbles of such exceptional ice specimens. In Photo. 2(b), it may be readily seen that each air bubble is much greater than those in Photo. 2(a). From this fact, it is clear that the charge depends also on the size of each air bubble. In other words, such big air bubbles seem to have no effect on the charge generation.

\section{Considerations}

From the experimental results described above, it was ascertained that the positive charge obtained in the melting processes of experimentally prepared specimens were approximately proportional to the air bubble concentration contained in ice specimens, and that the charge depends not only on the total volume of air bubbles in the specimens but also on the size of the bubble. In this experiment, the diameters ranged from several $\mu$ to $150 \mu$ with the mean volume diameter of $52 \mu$. Accordingly, the mean volume of one air bubble $(\bar{v})$ was $8 \times 10^{-8} \mathrm{~cm}^{3}$. The ratio $(Q / V)$ of the charge of the melted ice $(Q / M)$ to the air bubble concentration in the melted ice $(V / M)$ was approximately 10 in Fig. 7, where $Q$ is the total charge of the melted ice specimen, $V$ is the total volume of air bubbles and $M$ is the mass of the melted ice specimen. Now, if $N$ is the total number of air bubbles, the mean generated charge per air bubble $(Q / N)$ is approximately $1 \times 10^{-6}$ esu. from $V=N \cdot \bar{v}$.

From previous observational results (Magono and Kikuchi, 1965) and the present experimental results, it was not possible to elucidate the mechanism as to how the air bubble contributed to the generation of positive charge on the melted ice specimens. However one of the contributing factors for the charge generation may be attributed to the effect of the scattering of the numerous small particles produced by the bursting bubbles from the surface of the melting ice. If it can be shown that the small particles carry negative charge, it may be explained that the melted ice acquired some positive charge. Dinger and Gunn (1946), Bent and Hutchinson (1965) considered that these small particle carried some negative charge by means of measurement of space charge produced by the charged particles. But the negative charge on individual particles was not observed directly. The scattering process of an air bubble might be produced by "film droplets" and " jet droplets" (Kientzler et al, 1954, Blanchard and Woodcock. 1957, Toba. 1959, Day. 1964). Matthews and Mason (1963) did not get any data of the charge due to melting. The reason for this may be that the artificial snowflakes used for specimens did not include sufficient number of air bubbles as seen in the experimental specimens used here.

\section{Acknowledgments}

The author expresses his gratitude to Prof. C. Magono for his guidance and encouragement throughout the course of this study. And also the author is most grateful to Prof. D. Kuroiwa, the Institute of Low Temperature Science, who permitted the use of cold room of the institute and to Prof. A. Higashi, Faculty of Technology, who provided some valuable single ice crystals.

The expense of this study was defrayed 
from the Special Fund for Science of the Education Ministry of Japan.

\section{References}

Bent, R.B. and W.C.A. Hutchinson, 1965 : Electric space charges over melting snow on the ground. J. atmos. terr. Phys., 27, 91-99.

Blanchard, D.C. and A.H. Woodcock, 1957: Bubble formation and modification in the sea and its meteorological significance. Tellus, 9, 145158.

Day, J.A., 1964: Production of droplets and salt nuclei by bursting of air-bubble films. Quart. J. Roy. meteor. Soc., 90, 72-78.

Dinger, J.E. and R. Gunn, 1946: Electrical effects associated with a change of state of water. Terr. Mag. Atmos. Elect., 51, 477-494.

Higashi, A., S. Hashimoto, K. Itagaki, H. Shimizu, S. Kumano, T. Takahashi and K. Kikuchi: to be published in Arctic.

Kientzler, C.F., A.B., Arons, D.C. Blanchard and A.H. Woodcock, 1954: Photographic investi. gation of the projection of droplets by bubbles bursting at a water surface. Tellus, 6, 1-7.

Kusunoki, K. 1958: Measurement of gas bubbles content in sea ice. I. (in Japanese) Low $\mathrm{Tcm}$. perature Science, Ser. A, 17, 123-134.

Magono, C. and K. Kikuchi, 1963: On the positive electrification of snow crystals in the process of their melting. J. meteor. Soc. Japan, Ser. II, 41, 270-277.

Magono, C. and K. Kikuchi, 1965: On the positive electrification of snow crystals in the process of their melting (II). J. meteor. Soc. Japan, Ser. II, 43, 331-342.

Magono, C. and K. Orikasa, 1960: On the surface electric field during rainfall. J. metcor. Soc. Japan, Ser. II, 38, 182-194.

Matthews, J.B. and B.J. Mason, 1963 : Electrification accompanying melting of ice and snow. Quart. J. Roy. meteor. Soc., 89, 376-380.

Toba, Y. 1959: Drop production by bursting of air bubbles on the sea surface (II). Theoretical study on the shape of floating bubbles. $J$. Ocean. Soc. Japan, 15, 121-130.

Шулейкин, В.В. 1953: Физика моря. Изд. ан СССР, Москва.

\title{
降雪の融解による正荷電について（III）
}

一氷飞含まれる気泡量と電荷量の関係一

\author{
菊地勝 弘 \\ 北海道大学理学部地球物理学教室
}

\begin{abstract}
これまでの実験および観測結果から, 雪の結晶や水の試料が融解する時飞, 正電荷を得ることが知られている。そ の際，雪の結晶や氷の試料の中含まれている気泡が何らかの形で電荷発生機棈飞関係していると考えられたので, 特飞氷飞含まれている気泡量と電荷量との関係を定量的飞調べた。

その結果, 融解過程飞拈いて, 承が獲得した正電荷量は, その試料含まれている気泡量飞ほぼ比例していること が明らかになった。またこの実験で, 電荷発生機構に奇与していると考えられる気泡の直径は数 $\mu$ から $150 \mu$ 程度 のものであって, mean volume diameter は $52 \mu$ であった。一方直径 $1 \mathrm{~mm}$ 以上の気泡はほとんど寄与していな かった。これらのことから融解の際の電荷発生には比較的小さな気泡が数多く必要なことがわかった。
\end{abstract}

